\title{
PENANGGULANGAN TINDAK PIDANA PORNOGRAFI DALAM MEDIA INTERNET
}

\author{
Oleh : Enik Isnaini, SH, MH
}

\begin{abstract}
Abstrak
Salah satu problem besar yang dibawa oleh teknologi informasi global melalui jaringaninternet adalah adanya berbagai situs yang menampilkan adegan pornografi. Seolah-olahsekarang ini sangat sulit untuk memproteksi jaringan internet dari serbuan pebisnis hiburanyang menjual pornografi.

Rumusan masalah yang diangkat penulis dalam skripsi ini adalah: (1) Bagaimana pelaksanaan penanggulangan tindak pidana pornografi dalam media internet, (2) Bagaimana sanksi hukum bagi pelaku tindak pidana pornografi dalam media internet. Maka metode pendekatan masalah yang digunakan dalam penelitian ini adalah menggunakan pendekatan perundang-undangandan pendekatan kasus yang kemudian bahan hukumnya diolah secara deduktif yakni menarik kesimpulan dari suatu permasalahan yang bersifat umum terhadap permasalahan kongkrit yang dihadapi yakni pornografi dalam media internet.

Dari rumusan masalah diperoleh jawaban bahwa pelaksanaan penanggulangan tindak pidana pornografi dalam media internet (Cyberporn) adalah dimulai dari dengan upaya membebaskan keluarga dari virus pornografi, menggugah kesadaran masyarakat, sampai peran serta aparatur pemerintah dalam pembuatan undang-undang tentang pornografi dan sanksi hukum bagi pelaku tindak pidana pornografi dalam media internet dimuat dalam KUHP, Undang-Undang Nomor 8 tahun 1992 Tentang Perfilman, Undang-undang nomor 40 tahun 1999 Tentang Pers, Undangundang No. 11 Tahun 2008 Tentang Informasi dan Transaksi Elektronik (ITE), Undang-undang No. 44 tahun 2008 Tentang Pornografi.

Melihat semakin maraknya tindak pidana pornografi di media internet maka perlu adanya upaya dan dukungan dari seluruh lapisan masyarakat yang terkait untuk menanggulangi pornografi karena masalah pornografi adalah suatu problema yang sangat kompleks dan memprihatinkan serta diperlukan suatu penanganan yang serius dari para penegak hukum untuk mengatasi masalah kasus pornografi yang semakin meresahkan masyarakat sesuai dengan peraturan perundang-undangan yang berlaku.
\end{abstract}

Kata Kunci : Tindak Pidana, Pornografi, Internet.

\section{PENDAHULUAN}

Globalisasi telah menjadi pendorong lahirnya era perkembangan teknologi informasi. Fenomena kecepatan perkembangan teknologi informasi ini telah merebak di seluruh belahan dunia. Tidak hanya negara maju saja, namun negara berkembang juga telah memacu perkembangan teknologi informasi pada masyarakatnya masing-masing, sehingga teknologi informasi mendapatkan kedudukan yang penting bagi kemajuan sebuah bangsa. ${ }^{1}$ Salah satu bagian dari teknologi informasi yang berkembang dengan pesat adalah sistem komputer yang dilengkapi dengan layanan internet.

Saat ini perkembangan internet mulai merambah dan menempati posisi yang kuat di antara berbagai media massa yang telah ada sebelumnya. Ketika internet mulai dikenal oleh masyarakat sekitar sepuluh tahun ini, sudah dapat diramalkan bahwa media ini akan sangat populer di kemudian hari.

Internet telah menghadirkan realitas kehidupan baru kepada umat manusia, di mana jarak dan waktu menjadi tidak terbatas. Melalui internet seseorang dapat melakukan berbagai aktivitas yang dalam dunia nyata sulit dilakukan karena terpisah oleh jarak, misalnya melakukan transaksi bisnis, mengobrol, berbelanja, belajar dan berbagai aktivitas lain seperti dalam kehidupan nyata.

Sama halnya dengan media massa pada umumnya yang berwujud, internet dapat dipandang sebagai media berpotensi untuk menyebarkan konten negatif. ${ }^{2}$ Salah satu problem besar yang dibawa oleh teknologi 
informasi global melalui jaringan internet adalah adanya berbagai situs yang menampilkan adegan pornografi. Seolaholah sekarang ini sangat sulit untuk memproteksi jaringan internet dari serbuan pebisnis hiburan yang menjual pornografi.

Perkembangan penyebaran pornografi pada akhir-akhir ini sudah sangat memprihatinkan, hal tersebut dapat terjadi karena jaringan internet secara potensial dapat melewati batas-batas negara dengan sporadis. Globalisasi telah menghapus sekatsekat yang ada dalam masyarakat, budaya barat yang serba terbuka (termasuk dalam hal ini pornografi) telah mempengaruhi budaya timur, khususnya Indonesia, yang terkenal dengan budaya yang sopan dan santun, lebih beretika, serta sangat kuat memegang norma-norma terutama norma agama. Pertemuan antar budaya ini telah melahirkan dua mata pisau, disatu sisi berdampak positif, namun di sisi lain berdampak negatif karena terjadi pergeseran yang sangat signifikan. ${ }^{3}$ Disadari atau tidak, kehadiran internet telah mempercepat penyebaran informasi ke seluruh dunia. Mengakses informasi, termasuk gambargambar porno, dapat dilakukan dengan mudah tanpa harus mengeluarkan uang dalam jumlah besar.

Komitmen suatu negara untuk memberantas pornografi tergantung pada politik hukum dan kondisi negara yang bersangkutan, hal ini sesuai dengan Konggres PBB Ke V tahun 1975 di Geneva, Swiss yang menyatakan bahwa dikriminalisasikan atau tindak pornografi atau kejahatan di bidang kesusilaan ini dihubungkan dengan kuat dan lemahnya hubungan antara moral dan hukum (law and moral standard) di negara yang bersangkutan. Indonesia merupakan negara yang bersifat religius, yakni moral menjadi hal yang dijunjung tinggi. Hal-hal yang bersifat pornografi maupun pornoaksi tetap menjadi persoalan yang banyak mengundang perhatian dan kecaman di masyarakat.

Penyebaran pornografi di internet dan dampak negatifnya juga menjadi permasalahan serius yang dihadapi oleh Indonesia. Selain situs porno impor, situs porno lokal juga sudah mulai menjamur di dunia maya. Situs-situs ini ada yang gratis dan ada pula yang bersifat komersil. Menteri Negara Komunikasi dan Informasi, Tifatul Sembiring, menyatakan bahwa 50\% (lima puluh persen) kaum muda lebih suka menggunakan internet untuk mencari dan membuka situs porno.

Pornografi anak di mata para netter dianggap hal sepele walau fatal akibatnya. Menjamurnya warnet membuat motif bisnis menjadi raja. Pornografi bias dijadikan konten bisnis yang menggiurkan dengan menampilkan berbagai media porno lewat internet. $^{6}$

Pornografi memang suatu hal yang sangat kompleks, karena ini tidak berdiri sendiri, melainkan kumpulan dari beberapa hal. Masalah tentang pornografi bukan hanya masalah pemerintah dan negara saja, tapi juga merupakan masalah kita bersama. Karena hal ini menyangkut kehidupan kita, dan akan berdampak pada diri kita semua. Hal ini dapat dilihat dengan banyaknya aksiaksi kejahatan seksualitas yang terjadi belakangan ini. sebagian besar dari motifnya adalah akibat dari konsumsi pornografi, baik dari media apapun, visual atau audio. Kurangnya ketegakan hukum dalam mengurus hal ini membuat pornografi menjadi suatu masalah sosial yang besar. Semua ini akan menjadi boomerang bagi bangsa Indonesia baik cepat atau lambat. oleh karena itu kerjasama pemerintah dan masyarakat sangat diperlukan dalam masalah pornografi ini.

Upaya penghentian penyebaran pornografi di internet tidak dapat berjalan apabila tidak didukung oleh peran serta masyarakat terutama masyarakat yang berkaitan dengan bidang internet dalam hal ini para pengusaha warung internet.

Masyarakat dituntut tanggung jawabnya terhadap kelangsungan generasi muda sebagai penerus bangsa. Peran serta masyarakat ini dapat dilakukan dengan pengawasan terhadap anak-anak dari pergaulan yang menjurus kepada hal-hal yang negatif. Selain itu masyarakat juga diwajibkan untuk melaporkan setiap indikasi adanya penyebaran pornografi oleh pihak- 
pihak tertentu yang dilarang oleh undangundang.

Sudah banyak peraturan perundangundangan yang memuat larangan penyebaran pornografi, diantaranya UndangUndang Nomor 40 Tahun 1999 Tentang Pers, Undang- Undang Nomor 32 Tahun 2002 Tentang Penyiaran, Undang-Undang Nomor 23 Tahun 2002 Tentang Perlindungan Anak. Peraturan perundangundangan tersebut dianggap kurang memadai dan belum memenuhi kebutuhan hukum untuk memberantas pornografi secara efektif. Oleh karena itu, sejak tahun 2006 telah bergulir pembahasan Rancangan Undang-Undang Anti Pornografi dan Pornoaksi (RUU APP) di Dewan Perwakilan Rakyat Republik Indonesia. Dalam perjalanannya, RUU APP berganti menjadi RUU Pornografi dan pada tanggal 30 Oktober 2008, DPR RI mengesahkan Undang-Undang Nomor 44 Tahun 2008 tentang Pornografi melalui Sidang Paripurna.

\section{SANKSI HUKUM BAGI PELAKU TINDAK PIDANA PORNOGRAFI DALAM MEDIA INTERNET}

\section{A. Sanksi Hukum}

Bila kita berbicara mengenai sanksi, maka perhatian kita memasuki ranah hukum positif. Hukum dan sanksi dapat diibaratkan dua sisi uang yang satu saling melengkapi. Hukum tanpa sanksi sangat sulit melakukan penegakan hukum, bahkan dapat dikatakan bahwa norma sosial tanpa sanksi hanyalah moral, bukan hukum, sebaliknya sanksi tanpa hukum dalam arti kaidah akan terjadi kesewenang-wenangan penguasa. Sanksi selalu terkait dengan norma hukum atau kaidah hukum dengan norma-norma lainnya, misalnya norma kesusilaan, norma agama atau kepercayaan, norma sopan santun Dengan sanksilah maka dapat dibedakan antara norma hukum dengan norma lainnya. Kaum positivisme termasuk Hart memandang hukum sebagai perintah dan menempatkan sanksi sebagai suatu yang melekat pada hukum, mengaitkan antara unsur paksaan dengan hierarki perintah secara formal. Mereka membedakan norma hukum dan norma-norma lainnya karena pada norma hukum dilekatkan suatu paksaan atau sanksi.

Selain norma hukum, terdapat norma sosial yang mengatur perilaku manusia terhadap sesamanya, yang biasa disebut "moral" dan disiplin ilmu yang ditujukan untuk memahami dan menjelaskannya disebut "etika". Antara keadilan dan kepastian hukum tercakup hubungan moral dengan hukum positif. Bila keadilan merupakan dalil atau tujuan dari moral, maka kepastian hukum merupakan tujuan dari hukum positif. Di mana tidak ada kepastian hukum, di situ tidak ada keadilan. Bila keadilan bersifat relatif, maka kepastian hukumlah yang menjadi kebenaran.

Keadilan adalah kebaikan yang memberikan apa yang menjadi hak semua orang. Sebuah negara merupakan sebuah komunitas hukum yang berkeadilan. Bila keadilan sejati tidak ada, maka hukum juga tidak ada. Karena apa yang diperbuat oleh hukum, diperbuat pula oleh keadilan, dan apa yang dilakukan secara tidak adil, berarti terjadi pelanggaran hukum. Hukum merupakan tatanan pemaksa yang adil dan dibedakan dari tatanan pemaksa pada kalangan perampok lantaran isinya yang berkeadilan.

Hukum yang sebenarnya memiliki empat unsur, yaitu (1) perintah (command), (2) Sanksi (sanction), (3) kewajiban (duty), dan (4) kedaulatan (sovereignty).Kaum positivisme termasuk Hart memandang hukum sebagai perintah dan menempatkan sanksi sebagai suatu yang melekat pada hukum, mengaitkan antara unsur paksaan dengan hierarki perintah secara formal. Mereka membedakan norma hukum dan norma-norma lainnya karena pada norma hukum dilekatkan suatu paksaan atau sanksi.

Hukum termasuk sollenskatagori atau sebagai keharusan, bukan seinskatagori atau sebagai kenyataan. Orang menaati hukum karena memang seharusnya ia menaati sebagai perintah negara. Melalaikan perintah akan mengakibatkan orang itu berurusan dengan sanksi. Aliran hukum positif memberikan penegasan terhadap hukum 
yaitu bentuk hukum adalah undang-Undang, isi hukum adalah perintah penguasa, ciri hukum adalah sanksi, perintah, kewajiban dan kedaulatan, sistematisasi norma hukum menurut Hans Kelsen adalah hierarki norma hukum. ${ }^{45}$

Sanksi tidak terlepas dari subjek hukum dan objek hukum (perbuatan hukum). Subjek hukum diartikan sebagai pendukung hak dan kewajiban yang terdiri dari manusia atau natuurlijke persoon dan badan hukum atau rechtspersoon. Subjek hukum dapat berupa perseorangan (manusia atau natuurlijke persoon) dan dapat juga sebagai korporasi yang artinya adalah suatu gabungan orang yang dalam pergaulan hukum bertindak bersama-sama sebagai satu subjek hukum tersendiri. Ini berarti bahwa korporasi merupakan badan hukum yang beranggota, tetapi mempunyai hak dan kewajiban sendiri yang terpisah dari hak dan kewajiban anggota masing-masingnya. Korporasi dapat berbadan hukum dan non-badan hukum. Badan Hukum terdiri atas Badan Hukum Publik dan Badan Hukum Privat/perdata. Badan hukum adalah perkumpulan atau organisasi yang didirikan dan dapat bertindak sebagai subjek hukum, misalnya dapat memiliki kekayaan, mengadakan perjanjian dan sebagainya. Sedangkan perbuatan yang dapat menimbulkan akibat hukum yakni tindakan seseorang berdasarkan suatu ketentuan hukum yang dapat menimbulkan hubungan hukum, yaitu akibat yang timbul dari hubungan hukum seperti perkawinan antara laki-laki dan wanita. Sedangkan Objek hukum berupa perbuatan melawan hukum harus terlebih dahulu dirumuskan unsur-unsurnya dalam suatu undang-undang atau hukum tertulis baru sanksi dapat diterapkan, bila tidak, sulit untuk mencapai kepastian hukum. Sanksi pun harus dituangkan ke dalam suatu rumusan undang-undang atau hukum tertulis demi menjaga pelanggaran hak-hak asasi setiap individu dari penguasa. ${ }^{46}$

Macam-macam sanksi hukum antara lain :

1. Sanksi hukum pidana

1) Sanksi hukum pidana pokok terdiri dari:
a. Pidana mati;
b. pidana penjara;
c. pidana kurungan;
d. pidana denda;
e. pidana tutupan

2) Sanksi hukum pidana tambahan terdiri dari :
a. pencabutan hak-hak tertentu;
b. perampasan barang-barang tertentu;
c. pengumuman putusan hakim

2. Sanksi administratif, berupa :

1) Pencabutan atau pembubaran seluruh atau sebagian fasilitas yang telah atau dapat diperoleh perusahaan, berupa pencabutan izin;

2) Tindakan Tata tertib, berupa penempatan perusahaan di bawah pengampuan;

3) Pembekuan operasional selama waktu tertentu.

3. Sanksi Perdata (ganti kerugian)

\section{B. Sanksi Hukum Pelaku Tindak Pidana Pornografi Dalam Media Internet}

Untuk mencegah dan memberantas adanya tindak pidana pornografi dalam media internet, perlu adanya sanksi tegas bagi para pelakunya, baik itu sanksi moral maupun sanksi hukum. Sanksi hukum sendiri sudah diatur dalam peraturan perundang-undangan. Sampai saat ini sudah ada peraturan perundang-undangan yang mengatur mengenai masalah pornografi, termasuk pornografi dalam media internet.

Peraturan perundang-undangan yang berkaitan dengan pornografi dalam media internet (cyberporn) antara lain:

1. KUHP berikut:

Pasal 282 KUHP menyatakan sebagai

(1) Barang siapa menyiarkan, mempertunjukkan atau menempelkan di muka umum tulisan, gambaran atau benda yang telah diketahui isinya dan yang melanggar kesusilaan; atau barang siapa dengan maksud untuk disiarkan, dipertunjukkan atau ditempelkan di muka umum, membikin 
tulisan, gambaran atau benda tersebut, memasukkannya ke dalam negeri, meneruskannya, mengeluarkannya dari negeri, atau mempunyainya dalam persediaan; ataupun barang siapa secara terang-terangan atau dengan mengedarkan surat tanpa diminta, menawarkannya atau menunjukkannya sebagai bisa didapat, diancam dengan pidana penjara paling lama satu tahun enam bulan atau denda paling tinggi tiga ribu rupiah.

(2) Barang siapa menyiarkan, mempertunjukkan atau menempelkan di muka umum tulisan, gambaran atau benda yang melanggar kesusilaan, ataupun barang siapa dengan maksud untuk disiarkan, dipertunjukkan atau ditempelkan di muka umum, membikinnya, memasukkannya ke dalam negeri, meneruskan, mengeluarkannya dari negeri, atau mempunyai dalam persediaan, ataupun barang siapa secara terang-terangan atau dengan mengedarkan surat tanpa diminta, menawarkan atau menunjukkannya sebagai bisa didapat, diancam, jika ada alasan kuat baginya untuk menduga, bahwa tulisan, gambaran atau benda itu melanggar kesusilaan, dengan pidana penjara paling lama sembilan bulan atau denda paling banyak tiga ratus rupiah.

(3) Kalau yang bersalah, melakukan kejahatan tersebut dalam ayat pertama, sebagai pencarian atau kebiasaan, dapat dijatuhkan pidana penjara paling lama dua tahun delapan bulan atau denda paling banyak lima ribu rupiah.

2. Undang-Undang Nomor 40 Tahun 1999 Tentang Pers

Pasal 5 ayat (1) menyatakan bahwa "Pers nasional berkewajiban memberitakan peristiwa dan opini dengan menghormati norma-norma agama dan rasa kesusilaan masyarakat serta asas praduga tak bersalah".

Pasal 18 ayat (2) menyatakan bahwa "Perusahaan yang melanggar ketentuan Pasal 5 ayat (1) dipidana dengan pidana denda paling banyak Rp. 500.000.000,00 (Lima Ratus Juta Rupiah)".

3. Undang-Undang Nomor 8 Tahun 1992 Tentang Perfilman

Pasal 33 menyatakan bahwa :

1) Untuk mewujudkan arah dan tujuan penyelenggaraan perfilman sebagaimana dimaksud dalam Pasal 3 dan Pasal 4, setiap film dan reklame film yang akan diedarkan, diekspor, dipertunjukkan, dan/atau ditayangkan wajib disensor.

2) Penyensoran dapat mengakibatkan bahwa sebuah film:

a. Diluluskan sepenuhnya;

b. Dipotong bagian gambar tertentu;

c. Ditiadakan suara tertentu;

d. Ditolaknya seluruh film; untuk diedarkan. Diekspor, dipertunjukkan, dan/atau ditayangkan.

3) Sensor film dilakukan, baik terhadap film dan reklame film yang dihasilkan oleh perusahaan pembuatan film maupun terhadap film impor.

4) Film dan reklame film yang telah lulus sensor diberi tanda lulus sensor oleh lembaga sensor film.

5) Selain tanda lulus sensor, lembaga sensor film juga menetapkan penggolongan usia penonton bagi film yang bersangkutan.

6) Film, reklame film, atau potongannya yang ditolak oleh lembaga sensor film dilarang diedarkan, diekspor, dipertunjukkan, dan/atau ditayangkan, kecuali untuk kepentingan penelitian dan/atau penegakan hukum.

7) Terhadap film yang ditolak oleh lembaga sensor film, perusahaan film atau pemilik film dapat mengajukan keberatan atau pembelaan kepada badan yang berfungsi memberikan pertimbangan dalam masalah perfilman. 
Pasal 40 menyatakan bahwa:

Dipidana penjara paling lama 5 (lima) tahun dan/atau denda paling banyak Rp. 50.000.000,00 (Lima Puluh Juta Rupiah)

a. Barang siapa dengan sengaja mengedarkan, mengekspor, mempertunjukkan dan/atau menayangkan film dan/atau rekleme film yang ditolak oleh lembaga sensor film sebagaimana dimaksud dalam Pasal 33 ayat (6); atau

b. Barang siapa dengan sengaja mengedarkan, mengekspor, mempertunjukkan dan/atau menayangkan potongan film dan/atau suara tertentu yang ditolak oleh lembaga sensor film sebagaimana dimaksud dalam Pasal 33 ayat (6); atau

c. Barang siapa dengan sengaja mengedarkan, mengekspor, mempertunjukkan dan/atau menayangkan film yang tidak disensor sebagaimana dimaksud dalam Pasal 33 ayat (1).

4. Undang-undang No. 11 Tahun 2008 Tentang Informasi dan Transaksi Elektronik (ITE)

Pasal 27 ayat (1) menyebutkan bahwa "Setiap orang dengan sengaja dan tanpa hak mendistribusikan dan/atau mentransmisikan dan/atau membuat dapat diaksesnya Informasi Elektronik dan/atau Dokumen Elektronik yang memilki muatan yang melanggar kesusilaan.”

Dari pasal tersebut bahwa yang dimaksud "kesusilaan" adalah sesuatu yang berbau pornografi dan pelakunya dikenakan sanksi 6 tahun dan/atau denda hingga satu miliar.

5. Undang- undang No. 44 Tahun 2008 Tentang Pornografi

a. Pasal 29 menyatakan bahwa "Setiap orang yang memproduksi, membuat, memperbanyak, menggandakan, menyebar-luaskan, menyiarkan, mengimpor, mengekspor, menawarkan, memperjualbelikan, menyewakan, atau menyediakan pornografi sebagaimana dimaksud dalam Pasal 4 ayat (1) dipidana dengan pidana penjara paling singkat 6 (enam) bulan dan paling lama 12 (dua belas) tahun dan/atau pidana denda paling sedikit Rp250.000.000,00 (dua ratus lima puluh juta rupiah) dan paling banyak Rp6.000.000.000,00 (enam miliar rupiah)."

b. Pasal 30 menyatakan bahwa "Setiap orang yang menyediakan jasa pornografi sebagaimana dimaksud dalam Pasal 4 ayat (2) dipidana dengan pidana penjara paling singkat 6 (enam) bulan dan paling lama 6 (enam) tahun dan/atau pidana denda paling sedikit Rp250.000.000,00 (dua ratus lima puluh juta rupiah) dan paling banyak Rp3.000.000.000,00 (tiga miliar rupiah)."

c. Pasal 31 menyatakan bahwa "Setiap orang yang meminjamkan atau mengunduh pornografi sebagaimana dimaksud dalam Pasal 5 dipidana dengan pidana penjara paling lama 4 (empat) tahun dan/atau pidana denda paling banyak Rp2.000.000.000,00 (dua miliar rupiah)."

d. Pasal 32 menyatakan bahwa "Setiap orang yang memperdengarkan,

mempertontonkan, memanfaatkan, memiliki, atau menyimpan produk pornografi sebagaimana dimaksud dalam Pasal 6 dipidana dengan pidana paling lama 4 (empat) tahun dan/atau pidana denda paling banyak Rp2.000.000.000,00 (dua miliar rupiah).

e. Pasal 33 menyatakan bahwa "Setiap orang yang mendanai atau memfasilitasi perbuatan sebagaimana dimaksud dalam Pasal 7 dipidana dengan pidana penjara paling singkat 2 (dua) tahun dan 
paling lama 15 (lima belas) tahun dan/atau pidana denda paling sedikit Rp1.000.000.000,00 (satu miliar rupiah) dan paling banyak Rp7.500.000.000,00 (tujuh miliar lima ratus juta rupiah).“

f. Pasal 34 meyatakan bahwa "Setiap orang yang dengan sengaja atau atas persetujuan dirinya menjadi objek atau model yang mengandung muatan pornografi sebagaimana dimaksud dalam Pasal 8 dipidana dengan pidana penjara paling lama 10 (sepuluh) tahun dan/atau pidana denda paling banyak Rp5.000.000.000,00 (lima miliar rupiah)."

g. Pasal 35 menyatakan bahwa "Setiap orang yang menjadikan orang lain sebagai objek atau model yang mengandung muatan pornografi sebagaimana dimaksud dalam Pasal 9 dipidana dengan pidana penjara paling singkat 1 (satu) tahun dan paling lama 12 (dua belas) tahun dan/atau pidana denda paling sedikit Rp500.000.000,00 (lima ratus juta rupiah) dan paling banyak Rp6.000.000.000,00 (enam miliar rupiah)."

h. Pasal 36 menyatakan bahwa "Setiap orang yang mempertontonkan diri atau orang lain dalam pertunjukan atau di muka umum yang menggambarkan ketelanjangan, eksploitasi seksual, persenggamaan, atau yang bermuatan pornografi lainnya sebagaimana dimaksud dalam Pasal 10 dipidana dengan pidana penjara paling lama 10 (sepuluh) tahun dan/atau pidana denda paling banyak Rp5.000.000.000,00 (lima miliar rupiah)."

i. Pasal 37 menyatakan bahwa "Setiap orang yang melibatkan anak dalam kegiatan dan/atau sebagai objek sebagaimana dimaksud dalam Pasal 11 dipidana dengan pidana yang sama dengan pidana sebagaimana dimaksud dalam Pasal 29, Pasal 30, Pasal 31, Pasal 32, Pasal 34, Pasal 35, dan Pasal 36, ditambah 1/3 (sepertiga) dari maksimum ancaman pidananya."

j. Pasal 38 menyatakan bahwa "Setiap orang yang mengajak, membujuk, memanfaatkan, membiarkan, menyalahgunakan kekuasaan, atau memaksa anak dalam menggunakan produk atau jasa pornografi sebagaimana dimaksud dalam Pasal 12 dipidana dengan pidana penjara paling singkat 6 (enam) bulan dan paling lama 6 (enam) tahun dan/atau pidana denda paling sedikit Rp250.000.000,00 (dua ratus lima puluh juta rupiah) dan paling banyak Rp3.000.000.000,00 (tiga miliar rupiah)."

k. Pasal 39 menyatakan bahwa "Tindak pidana sebagaimana dimaksud dalam Pasal 29, Pasal 30, Pasal 31, Pasal 32, Pasal 33, Pasal 34, Pasal 35, Pasal 36, Pasal 37, dan Pasal 38 adalah kejahatan."

1. Pasal 40 menyatakan bahwa :

(1) Dalam hal tindak pidana pornografi dilakukan oleh atau atas nama suatu korporasi, tuntutan dan penjatuhan pidana dapat dilakukan terhadap korporasi dan/atau pengurusnya.

(2) Tindak pidana pornografi dilakukan oleh korporasi apabila tindak pidana tersebut dilakukan oleh orang-orang, baik berdasarkan hubungan kerja maupun berdasarkan hubungan lain, bertindak dalam lingkungan korporasi tersebut, baik sendiri maupun bersamasama.

(3) Dalam hal tuntutan pidana dilakukan terhadap suatu korporasi, korporasi tersebut diwakili oleh pengurus. 
(4) Pengurus yang mewakili korporasi sebagaimana dimaksud pada ayat (3) dapat diwakili oleh orang lain.

(5) Hakim dapat memerintahkan pengurus korporasi supaya pengurus korporasi menghadap sendiri di pengadilan dan dapat pula memerintahkan pengurus korporasi supaya pengurus tersebut dibawa ke sidang pengadilan.

(6) Dalam hal tuntutan pidana dilakukan terhadap korporasi, panggilan untuk menghadap dan penyerahan surat panggilan tersebut disampaikan kepada pengurus di tempat tinggal pengurus atau di tempat pengurus berkantor.

(7) Dalam hal tindak pidana pornografi yang dilakukan korporasi, selain pidana penjara dan denda terhadap pengurusnya, dijatuhkan pula pidana denda terhadap korporasi dengan ketentuan maksimum pidana dikalikan 3 (tiga) dari pidana denda yang ditentukan dalam setiap pasal dalam Bab ini.

m. Pasal 41 menyatakan bahwa :

Selain pidana pokok sebagaimana dimaksud dalam Pasal 40 ayat (7), korporasi dapat dikenai pidana tambahan berupa:

a. pembekuan izin usaha;

b. pencabutan izin usaha;

c. perampasan kekayaan hasil tindak pidana, dan pencabutan status badan hukum.

\section{PENUTUP}

\section{Kesimpulan}

1. Pelaksanaan penanggulangan tindak pidana pornografi dalam media internet adalah dimulai dari dengan upaya membebaskan keluarga dari virus pornografi, menggugah kesadaran masyarakat, sampai peran serta aparatur pemerintah dalam pembuatan undangundang tentang pornografi.

2. Sanksi hukum bagi pelaku tindak pidana pornografi dalam media internet dimuat dalam KUHP, Undang-Undang Nomor 8 tahun 1992 Tentang Perfilman, Undangundang nomor 40 tahun 1999 Tentang Pers, Undang-undang No. 11 Tahun 2008 Tentang Informasi dan Transaksi Elektronik (ITE), Undang-undang No. 44 tahun 2008 Tentang Pornografi

\section{Saran}

1. Diperlukan upaya dan dukungan dari seluruh lapisan masyarakat yang terkait untuk menanggulangi pornografi karena masalah pornografi adalah suatu problema yang sangat kompleks dan memprihatinkan

2. Perlu adanya suatu penanganan yang serius dari para penegak hukum untuk mengatasi masalah kasus pornografi yang semakin meresahkan masyarakat sesuai dengan peraturan perundangundangan yang berlaku

\section{DAFTAR PUSTAKA}

A. , Achmad. 2014. Pengertian Internet dan Sejarah Internet. http://www.likethisya.com/pengertianinternet.html. diakses 20 Juni 2014

Ini Dia, Sejarah Industri Pornografi. https:// groups.yahoo.com/ neo/ groups/ SuratKabar-Indonesia/ conversations/topics/199. diakses 10 Juni 2014

Keluarga Besar Mahasiswa Peradilan Agama UIN Syarif Hidayatullah Jakarta. 2014.

Pertanggungjawaban Pelaku Tindak Pidana Pornografi.2014. http://kbpauinjkt.blogspot.com/2010/11/tindakpidana-pornografi-dan pornoaksi 5823.html. diakses 22 Juni 2014 
Prodjodikoro, Wirjono. 2003. Asas-Asas Hukum Pidana di Indonesia. Bandung: Refika Aditama.

Prodjodikoro, Wirjono. 2003. TindakTindak Pidana Tertentu di Indonesia. Bandung: Refika Aditama.

R, Juniarso. 2014. Penanggulangan Tindak Pidana Pornografi Melalui Media Elektronik Internet Berdasarkan Undang-Undang Nomor 44 Tahun 2008 Tentang Pornografi Dihubungkan Dengan UndangUndang Nomor 11 Tahun 2008 Tentang Informasi Dan Transaksi Elektronik.

http://repository.fhunla.ac.id/?q=nod e/48. diakses 9 Juni 2014

Raharjo, Agus. 2002. Cybercrime Pemahaman dan Upaya Pencegahan Kejahatan Berteknologi, Bandung : PT Citra Aditya Bakti

$\underline{\text { Sanksi }}$ Hukum. 2014. http://tadjuddin.blogspot.com/2012/0 2/sanksi-hukum.html Diakses 05 Juni 2014.

Sari, Eka Purnama. 2014. Penanggulangan Tindak Pidana Pornografi dan Pornoaksi

diInternet.http://www.savepageaspdf .com/7672feef29e44575a59acdc04ee 72e7f/PENANGGULANGAN\%20T INDAK\%20PIDANA.htm, diakses 9 Juni 2014

Soesilo, R. 1988. Kitab Undang-Undang Hukum Pidana serta KomentarKomentarnya Lengkap Pasal Demi Pasal. Bogor: Politeia.

Suhariyanto, Budi. 2012. Tindak Pidana Teknologi Informasi (Cybercrime), Urgensi Pengaturan dan Celah Hukumnya, Jakarta : Rajawali Pers
Sunggono, Bambang. 2002. Metodologi Penelitian Hukum, Jakarta: PT Raja Grafindo Persada

Tindak Pidana Pornografi dan Pornoaksi Menurut Hukum Islam dan Hukum Positif. diakses 18 Juni 2014

Undang-Undang Nomor 23 Tahun 2002 tentang Perlindungan Anak.

Undang-Undang Nomor 32 Tahun 2002 tentang Penyiaran.

Undang-Undang Nomor 40 Tahun 1999 tentang Pers.

Undang-Undang Nomor 44 Tahun 2008 tentang Pornografi.

Wilanda, Mirza. 2014. Teori Sebab dan Penanggulangan Kejahatan, http:// mirzabrexs. blogspot.com /2014/03/ teori-sebab-dan- penanggulangankejahatan.html. diakses 12 Juni 2014 